Article

\title{
Inhibition of Ceramide Glycosylation Enhances Cisplatin Sensitivity in Cholangiocarcinoma by Limiting the Activation of the ERK Signaling Pathway
}

\author{
Piyasiri Chueakwon $^{1}$, Peeranat Jatooratthawichot ${ }^{1} \mathbb{D}$, Krajang Talabnin ${ }^{2}{ }^{\mathbb{D}}$, James R. Ketudat Cairns ${ }^{1}$ (D) \\ and Chutima Talabnin ${ }^{1, * \mathbb{D}}$ \\ 1 School of Chemistry, Institute of Science, Suranaree University of Technology, \\ Nakhon Ratchasima 30000, Thailand; p.chueakwon@gmail.com (P.C.); pj.cbsfa@gmail.com (P.J.); \\ cairns@sut.ac.th (J.R.K.C.) \\ 2 School of Pathology, Institute of Medicine, Suranaree University of Technology, \\ Nakhon Ratchasima 30000, Thailand; krajang.t@sut.ac.th \\ * Correspondence: chutima.sub@sut.ac.th
}

check for updates

Citation: Chueakwon, P.;

Jatooratthawichot, P.; Talabnin, K.; Ketudat Cairns, J.R.; Talabnin, C. Inhibition of Ceramide Glycosylation Enhances Cisplatin Sensitivity in Cholangiocarcinoma by Limiting the Activation of the ERK Signaling Pathway. Life 2022, 12, 351. https:// doi.org/10.3390/life12030351

Academic Editor: Riccardo Autelli

Received: 25 January 2022

Accepted: 25 February 2022

Published: 28 February 2022

Publisher's Note: MDPI stays neutral with regard to jurisdictional claims in published maps and institutional affiliations.

Copyright: (C) 2022 by the authors. Licensee MDPI, Basel, Switzerland. This article is an open access article distributed under the terms and conditions of the Creative Commons Attribution (CC BY) license (https:// creativecommons.org/licenses/by/ $4.0 /)$.

\begin{abstract}
Cholangiocarcinoma (CCA) is an aggressive tumor of the biliary epithelium with poor survival that shows limited response to conventional chemotherapy. Increased expression of glucosylceramide synthase (GCS) contributes to drug resistance and the progression of various cancers; the expression profiles of GCS (UGCG) and the genes for glucocerebrosidases 1, 2, and 3 (GBA1, GBA2, and GBA3) were therefore studied in CCA. The biological functions of GCS for cell proliferation and cisplatin sensitivity in CCA were explored. GCS expression was higher in CCA tumor tissues than that of GBA1, GBA2, and GBA3. Verification of GCS expression in 29 paired frozen CCA tissues showed that 8 of 29 cases $(27.6 \%$ ) had high GCS expression. The expression of GCS and GBA2 was induced in CCA cell lines following low-dose cisplatin treatment. Suppression of GCS by either palmitoylamino-3-morpholino-1-propanol (PPMP), GCS knockdown or a combination of the two resulted in reduced cell proliferation. These treatments enhanced the effect of cisplatin-induced CCA cell death, increased the expression of apoptotic proteins and reduced phosphorylation of ERK upon cisplatin treatment. Taken together, inhibition of the GCS increased cisplatin-induced CCA apoptosis via the inhibition of the ERK signaling pathway. Thus, targeting GCS might be a strategy for CCA treatment.
\end{abstract}

Keywords: glucosylceramide synthase; PPMP; cisplatin; sensitivity; cholangiocarcinoma

\section{Introduction}

Cholangiocarcinoma (CCA) is one of the most common aggressive malignancies of the bile duct epithelium, with an increasing worldwide incidence, particularly in Southeast Asia and Eastern Europe [1]. Late diagnosis, inoperable advanced stage, and resistance to chemotherapy remain major obstacles to CCA treatment [2,3]. Conventional chemotherapeutic agents-including 5-fluorouracil, cisplatin, leucovorin, mitomycin, gemcitabine, and cisplatin-have been used either alone or in combination with a response rate ranging between 20 and 30\% [4,5]. The current first-line chemotherapeutic regimen used in CCA treatment is a combination of gemcitabine and cisplatin [6]. However, the effectiveness of this regimen has been modest as the 5-year survival of 564 CCA patients between 1973 and 2004 was $18 \%$ [7,8]. A new treatment option for CCA is thus urgently needed.

Cisplatin, a platinum-based drug, is a chemotherapeutic drug widely applied in various types of cancers, including CCA. Cisplatin is usually combined with 5-fluorouracil or gemcitabine to increase the response rate and overall survival of CCA patients [9]. According to its cytotoxic mode of action, cisplatin mainly interacts with DNA, leading to DNA adduct-induced DNA damage and subsequent induction of apoptosis through 
the activation of the p53 and MAPK pathways [10]. Numerous studies have demonstrated that cisplatin-induced cell apoptosis is involved in an imbalance in sphingolipid levels. Ceramide (Cer) is a second messenger in sphingolipid metabolism which can function as a potent tumor suppressor lipid to mediate cell death by triggering cell growth arrest as an inducer of apoptosis, necroptosis, and mitophagy [11,12]. Induction of ceramide generation has been characterized as another cytotoxic mode of cisplatin leading to ceramide-mediated mitochondrial apoptosis and/or ceramide-mediated death through the Fas pathway [13-15].

Ceramide glycosylation is the first step in the biosynthesis of glycosphingolipids, and it has been implicated in the multi-drug resistance of various cancers [16]. Ceramide glycosylation occurs by the action of glucosylceramide synthase (GCS), which is encoded by the GCS (UGCG) gene. GCS is a transmembrane protein at the Golgi surface, converting Cer to a precursor of most of the complex glycosphingolipids (GSLs), glucosylceramide (GlcCer), by transferring the glucosyl residue from UDP-glucose to the hydroxyl group at $\mathrm{C} 1$ of ceramide [17]. Notwithstanding, the level of GlcCer is regulated by hydrolysis, either in the lysosome by glucocerebrosidase 1 (GBA1) or on the cytoplasmic side of the ER and Golgi membranes by glucocerebrosidase 2 (GBA2) [18]. Up-regulation of GCS expression has been reported in multiple cancer types, including cervical [19], breast [12], lung [20], colon $[19,21]$, and hepatocellular carcinoma [22]. Its expression is correlated with various aspects of cancer progression, including chemotherapeutic drug resistance, cell growth, and stemness properties through the activation of the AKT/ERK and c-Src/ $\beta$-catenin signaling pathways [12]. Currently, several lines of evidence have confirmed that GCS plays a major role in resistance to a variety of chemotherapeutic agents through the up-regulation of multi-drug resistant genes (MDR1) [12]. Therefore, the targeting of GCS is considered a means of overcoming cancer progression and drug resistance in various cancers; however, the GCS expression level in CCA and its role in CCA chemoresistance remains unknown. In the current study, the expression level of GCS was determined in CCA tissues and CCA cell lines. The biological effects of GCS on CCA cell growth, cisplatin sensitivity, and its underlying mechanisms were studied.

\section{Materials and Methods}

\subsection{GEO Database}

Gene expression data of CCA were retrieved from the public database-Gene Expression Omnibus (GEO) (https://www.ncbi.nlm.nih.gov/geo/, accessed on 13 April 2020)—through GEO series GSE76297 [23] on 13 April 2020. GEO series GSE76297 contains the expression data from 91 CCA tumors and 92 paired non-tumors. All expression data were $\log 2$ transformed.

\subsection{CCA Tissue Samples and Cell Lines}

The twenty-nine frozen CCA tissues and paired adjacent tissues were obtained from the specimen bank of the Cholangiocarcinoma Research Institute, Khon Kaen University. Informed consent was obtained from each patient. The research protocol was reviewed and approved by the Ethics Committee for Human Research of Khon Kaen University (HE521209) and Suranaree University of Technology (EC-57-25).

Two human CCA cell lines (KKU-100 and KKU-213A) were established and authenticated $[24,25]$. Certificates of analyses were obtained from the Japanese Collection of Research Bioresources Cell Bank. The cells were cultured in DMEM (Thermo Fischer Scientific, Grand Island, NY, USA) supplemented with 1\% penicillin-streptomycin (Thermo Fischer Scientific, Grand Island, NY, USA) and 10\% FBS (Thermo Fischer Scientific, Grand Island, NY, USA) and maintained in a humidified incubator with $5 \% \mathrm{CO}_{2}$ at $37^{\circ} \mathrm{C}$. Mycoplasma testing was performed for the cell lines using PCR detection and Hoechst 33258 staining Dye solution (H3569, Thermo Fischer Scientific, Waltham, MA, USA). 


\subsection{Quantitative Real-Time PCR ( $q P C R$ )}

Total RNA was extracted using Trizol (Thermo Fischer Scientific, USA) according to the manufacturer's instructions. cDNA was then synthesized using a SensiFAST cDNA Synthesis Kit (Bioline, Memphis, TN, USA). Quantitative real-time PCR was performed to evaluate the gene expression levels of GCS (UGCG) GBA1 and GBA2 using a LightCycler ${ }^{\circledR}$ 480 SYBR Green I Master (Roche Diagnostic, Mannheim, Germany). The primer sequences were: GBA1 primer (forward: 5'-GTT CCA GAA AGT GAA GGG AT- $3^{\prime}$ and reverse $5^{\prime}$-TTC TCT GAA GAA GGA ATC GG-3'); human GBA2 primer (forward: 5'-CCA CTA CAG GCG GTA TAC AA- $3^{\prime}$ and reverse $5^{\prime}$-GAT CTG TCA TCC AAT ACC GG-3'); GCS (UGCG) primer (forward: $5^{\prime}$-TGC TCA GTA CAT TGC CGA AGA-3' and reverse $5^{\prime}$-TGG ACA TTG CAA ACC TCC AA- $3^{\prime}$ ); c-Myc primer (forward: $5^{\prime}-\mathrm{CTG}$ CTG TGG ACC CTA CTG-3' and reverse: $5^{\prime}$-AAC TGC GTC TCT GCC AGG AC-3'); CCND1 primer (forward: $5^{\prime}$-CCA CTT GAG CTT GTT CAC CA-3' and reverse $5^{\prime}$-AAC TAC CTG GAC CGC TTC CT- $3^{\prime}$ ); CDK4 primer (forward: $5^{\prime}$-GTC GGC TTC AGA GTT TCC AC-3' and reverse $5^{\prime}$-TGC AGT CCA CAT ATG CAA CA-3'); and CCNB1 primer (forward: $5^{\prime}$-GAC AAC TTG AGG AAG AGC AAG C- $3^{\prime}$ and reverse $5^{\prime}$-ATG GTC TCC TGC AAC AAC CT- $3^{\prime}$ ). $\beta$-actin was used as an internal control (forward: $5^{\prime}$-GAT CAG CAA GCA GGA GTA TGA CG-3' and reverse $5^{\prime}$-AAG GGT GTA ACG CAA CTA AGT CAT AG-3'). Gene amplification was performed for 40 cycles of denaturation at $95{ }^{\circ} \mathrm{C}$ for $10 \mathrm{~s}$, annealing at $58{ }^{\circ} \mathrm{C}$ for $10 \mathrm{~s}$, and extension at $72{ }^{\circ} \mathrm{C}$ for $10 \mathrm{~s}$. The melting curve $(1 \mathrm{cycle})$ was at $95^{\circ} \mathrm{C}$ for $10 \mathrm{~s}$ and $65^{\circ} \mathrm{C}$ for $1 \mathrm{~min}$. Annealing at $58{ }^{\circ} \mathrm{C}$ was used for all primers. The relative gene expression levels were normalized with an internal control ( $\beta$-actin) calculated by $2^{-\Delta \Delta C T}[26]$.

\subsection{Protein Collection and Immunoblotting}

CCA cells were lysed in lysis buffer: $150 \mathrm{mM} \mathrm{NaCl} ; 50 \mathrm{mM}$ Tris-HCl pH 7.4; 1\% Sodium deoxycholate; $0.1 \%$ SDS; and 1X Protease inhibitor cocktail tablets (Roche Diagnostic, Mannheim, Germany) to obtain whole cell lysates. The protein concentration of all samples was determined with the Pierce BCA Protein Assay Kit (Thermo Scientific, Rockford, IL, USA). Equal amounts of proteins ( $30 \mu \mathrm{g} /$ lane) were resolved by SDS-PAGE (SDS-polyacrylamide gel electrophoresis) using $12 \%$ polyacrylamide gel. The proteins were then transferred onto a nitrocellulose membrane (GE Healthcare, Buckinghamshire, UK). The membrane was incubated in 5\% skim milk PBST at room temperature for blocking non-specific proteins. Primary antibodies were then probed at $4{ }^{\circ} \mathrm{C}$, overnight, including GCS (ab124296, Abcam, Cambridge, UK), PARP1 (13371-1), BAX (50599-2), BCL-2 (12789-1) (Proteintech, Rosemont, IL, USA), caspase-3 (\#9662), cleaved caspase-3 (c-caspase 3) (\#9661), AKT (\#4685), phosphorylated AKT (pAKT) (\#4060), ERK1/2 (\#4695), phosphorylated ERK1/2 (pERK) (\#9101) (Cell signaling, USA), and $\beta$-actin (sc-47778, Santa Cruz Biotechnology, USA). All antibodies were diluted to 1:1000-1:5000. The membrane was then washed with PBST and incubated with horseradish peroxide-conjugated secondary antibodies (1:2000, GE Healthcare, Buckinghamshire, UK). Immunodetection by chemiluminescent HRP substrate was used to visualize the target protein signals (GE Healthcare, Buckinghamshire, UK). Image J software (version 1.53a; National Institutes of Health, Bethesda, MD, USA) was used to determine the density of each target protein, then the relative intensity of the protein band was transformed into a quantitative value. The ratio of each protein band intensity to that of $\beta$-actin was calculated for normalization.

\subsection{Inhibition of GCS by Specific-siRNA}

CCA cell lines were plated at $3.5 \times 105$ cells in 6-well plates. After overnight culture, the cells were transfected with either $10 \mu \mathrm{M}$ siCTRL (sc-37007, Santa Cruz Biotechnology, Santa Cruz, CA, USA) or $10 \mu \mathrm{M}$ siGCS (sc-45404, Santa Cruz Biotechnology, Santa Cruz, CA, USA), using DharmaFECT transfection reagents (Horizon, Ireland) in OptiMEM (Thermo Fischer Scientific, Grand Island, NY, USA) for 24 and $48 \mathrm{~h}$. The transfection procedure was performed according to the recommendations of the manufacturer. 


\subsection{Sulforhodamine B (SRB) Assay}

Cell viability was assessed by the SRB assay. First, the cells were fixed in 10\% $(w / v)$ tricarboxylic acid (TCA) at $4{ }^{\circ} \mathrm{C}$ overnight. After washing, the cells were then stained with SRB dye for $30 \mathrm{~min}$. Next, the residual dye was washed out with $1 \%(v / v)$ acetic acid. The dye-binding proteins were then dissolved in $10 \mathrm{mM}$ Tris base. The absorbance at $564 \mathrm{~nm}$ was measured in a microplate reader (Bio-Rad Laboratories, Inc., Hercules, CA, USA) to determine cell viability.

\subsection{Cell Proliferation}

CCA cells were seeded at $5 \times 103$ cells per well in 96-well plates at $37^{\circ} \mathrm{C}$. After $24 \mathrm{~h}$ seeding, the cells were then exposed with or without $10 \mu \mathrm{M}$ D,L-threo-1-Phenyl-2palmitoylamino-3-morpholino-1-propanol hydrochloride (PPMP, sc-205655, Santa Cruz Biotechnology, Santa Cruz, CA, USA) and continuously incubated at $37^{\circ} \mathrm{C}$ for 24 and $48 \mathrm{~h}$. The cell viability was assessed using the SRB assay. For GCS silencing, the cells were treated with siCTRL or siGCS in 6-well plates. After siRNA transfection, the cells were seeded into 96-well plates overnight, and viable cells were determined using the SRB assay at 24 and $48 \mathrm{~h}$.

\subsection{Drug Treatment}

In order to evaluate the cytotoxicity effect of cisplatin in CCA cell lines, the cells were seeded at $7 \times 103$ cells per well in 96 -well plates at $37^{\circ} \mathrm{C}$ for $24 \mathrm{~h}$. Then the cells were treated with cisplatin at various concentrations $(0,20,40$, and $60 \mu \mathrm{M})$ for another 24 and $48 \mathrm{~h}$. After investigating the effect of GCS suppression on cisplatin treatment, the GCS-silencing and control cells were seeded into 96-well plates. After seeding for $24 \mathrm{~h}$, the cells were treated with (a) cisplatin alone at 10 and $20 \mu \mathrm{M}$; (b) D,L-threo-1-Phenyl2-palmitoylamino-3-morpholino-1-propanol hydrochloride (PPMP) alone at $10 \mu \mathrm{M}$; and (c) co-treatment of cisplatin and PPMP for 24 and $48 \mathrm{~h}$. Cell viability was determined by the SRB assay. The half-maximal inhibitory concentration (IC50) was calculated with GraphPad Prism 8 (GraphPad Software, San Diego, CA, USA).

\subsection{Statistical Analysis}

The data were analyzed with GraphPad Prism 8 (GraphPad Software, San Diego, CA, USA) and IBM SPSS 22.0 software (IBM Corporation, Armonk, NY, USA). The data were expressed as means \pm SEMs of at least three independent experiments. The correlation of gene expression data of tumor versus non-tumor from the GEO database was evaluated using the Mann-Whitney test. A Chi-square test was used to analyze the relationship between the expression of GCS and clinical data. Survival analysis was plotted using a Kaplan-Meier curve, and the log-rank test was used to compare curves. A paired sample $t$-test was used to compare sets of paired data. One- and two-way ANOVA were used to compare the two groups for one and two independent variables, respectively. All statistical analyses were two-sided. $p<0.05$ was considered statistically significant.

\section{Results}

\subsection{Glucosylceramide Synthase (GCS) Expression in Cholangiocarcinoma Tissues}

In order to explore the expression level of ceramide-metabolizing enzymes (Figure 1A), including GCS, GBA1, GBA2, and GBA3 in CCA tissues, we first retrieved the expression data of the four genes from the GEO database (GEO Series GSE76297). Then, the differential expression of the four genes was compared between CCA tumor tissues and non-tumor tissues. Both the GCS and the GBA1 expression levels were significantly up-regulated in CCA tumor tissues (Figure 1B,C), whereas the GBA2 and GBA3 were down-regulated compared with matched paired non-tumor CCA tissues (Figure 1D,E). Additionally, the expression level of GCS was higher in the CCA tumor tissues than the other glucocerebrosidase (GBA1, GBA2, and GBA3). GCS expression was further verified in 29 frozen paired CCA tumor tissues and adjacent normal tissues via qPCR (Figure 2A). At a cut-off value set at 1.5-fold 
difference, high GCS expression was found in $27.6 \%$ (8/29 cases) of tumor tissues, whereas in the remaining $72.4 \%(21 / 29)$ of cases, GCS expression was low (Figure 2B). The finding suggests that altered expression of ceramide-metabolizing enzymes occurs in CCA.

In order to address the significance of GCS expression in CCA, we investigated the association between GCS expression and overall survival or clinicopathological features. The Kaplan-Meier analysis revealed no statistically significant correlation between GCS expression and overall survival (log-rank test, $p=0.67$ ) (Figure 2C). The univariate analysis demonstrated that there was no statistically significant difference between GCS expression and any clinicopathological variables (including age, sex, tumor stages, node lymphatic invasion, and histological types) (Table 1).

A

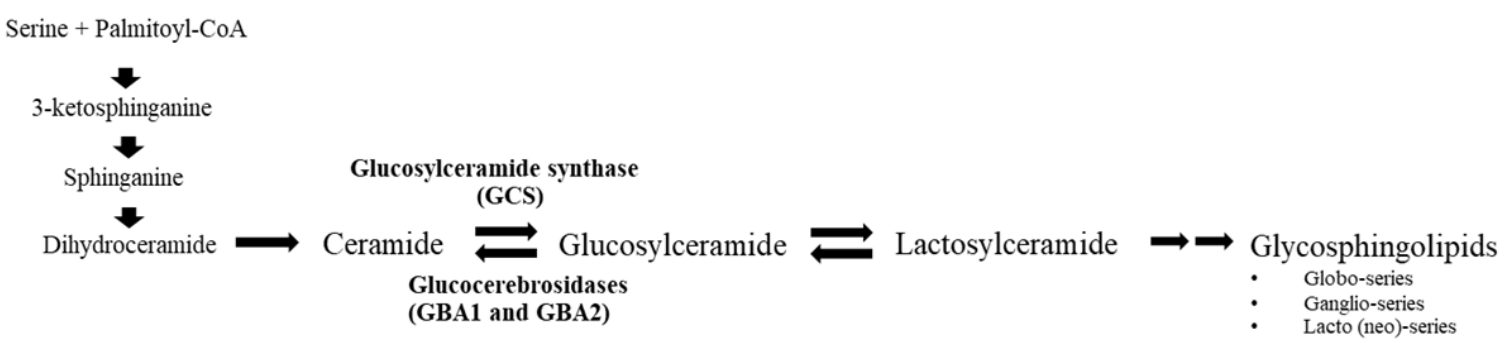

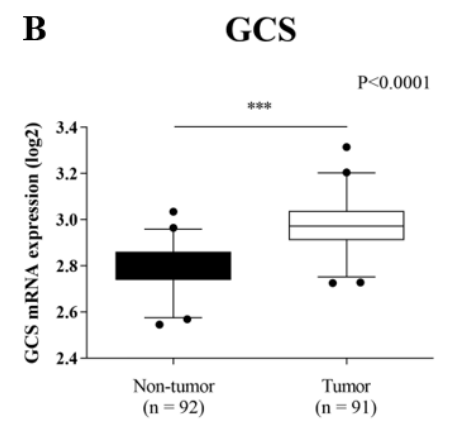

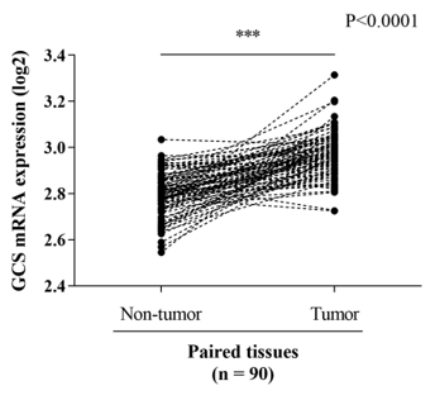

C $\quad$ GBA1

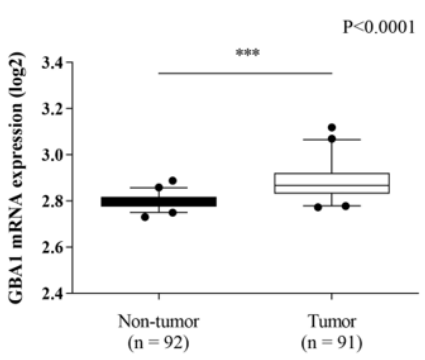

D
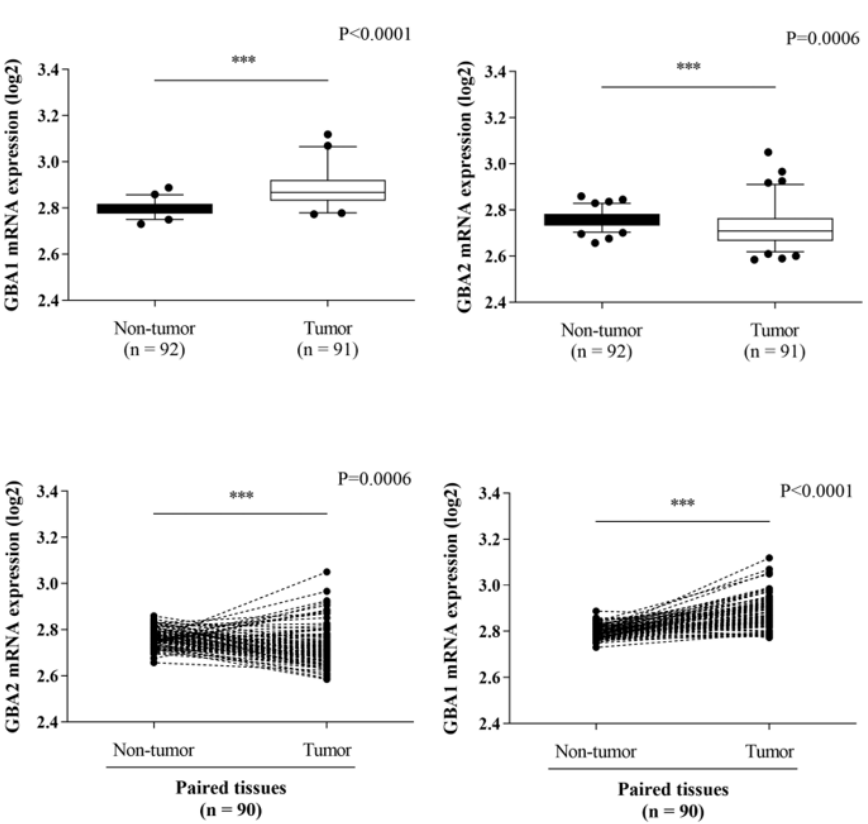

- Ganglio-series

Lacto (neo)-series

Figure 1. Expression of ceramide-metabolizing enzymes in paired CCA tissues. (A) Diagram of the sphingolipids biosynthesis pathways. Expression data were obtained from the GEO database (GSE76297 dataset) for a comparison of: (B) GCS mRNA expression, (C) GBA1 mRNA expression, (D) GBA2 mRNA expression and (E) GBA3 mRNA expression. The Mann-Whitney was used to compare the expression between tumor $(n=92)$ and non-tumor tissues $(n=91)$ as well as paired tissues. $^{* * *}, p<0.001$ versus non-tumor tissues. 


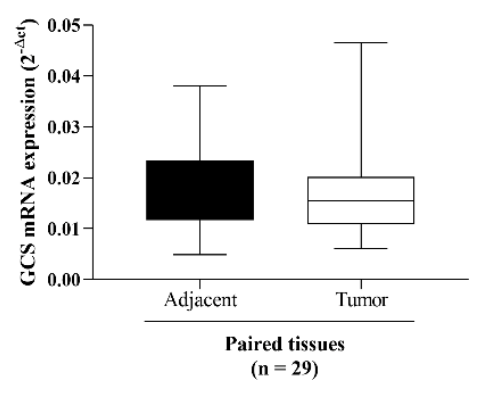

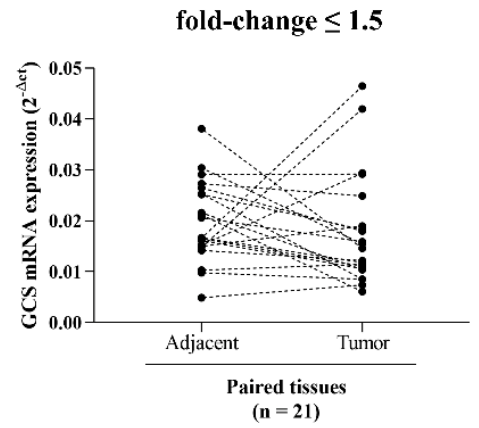

$\mathbf{C}$

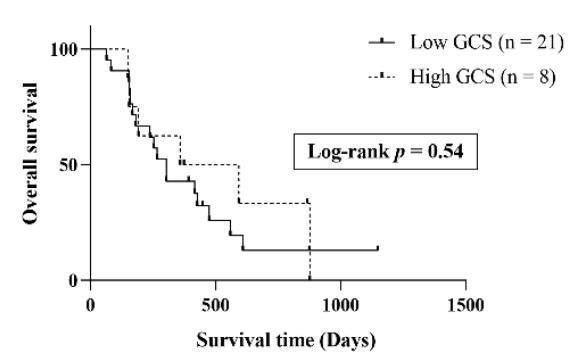

fold-change $>1.5$

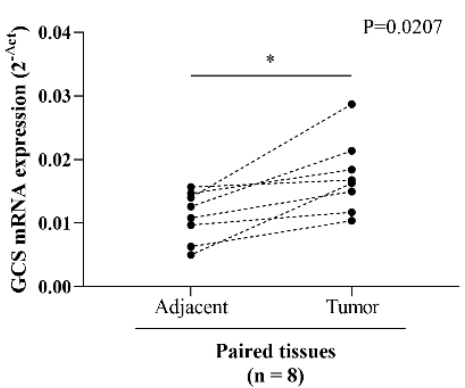

Figure 2. GCS expression in 29 paired frozen CCA tissues. (A) GCS mRNA expression was determined by qPCR. (B) Cut-off at 1.5-fold change (tumor/adjacent normal) was used for dichotomized GCS mRNA expression in 2 groups. Cut-off value $\leq 1.5$-fold change and $>1.5$-fold change denoted as low and high GCS expression, respectively. (C) Kaplan-Meier analysis of overall survival in low and high GCS cases. Log Rank test was used for survival analysis. * $p<0.05$ versus adjacent normal tissues.

Table 1. Association of GCS expression and clinicopathological features in CCA patients.

\begin{tabular}{|c|c|c|c|c|}
\hline \multirow{2}{*}{ Clinicopathological Feature } & \multirow{2}{*}{$\begin{array}{l}\text { Cases } \\
(n=29)\end{array}$} & \multicolumn{2}{|c|}{ GCS mRNA Expression Levels \# } & \multirow{2}{*}{$p$-Value * } \\
\hline & & Low & High & \\
\hline \multicolumn{5}{|l|}{ Sex } \\
\hline Male & 15 & 10 & 5 & \multirow{2}{*}{0.474} \\
\hline Female & 14 & 11 & 3 & \\
\hline \multicolumn{5}{|l|}{ Age (years old) } \\
\hline$\leq 50$ & 5 & 4 & 1 & \multirow{2}{*}{0.677} \\
\hline$>50$ & 24 & 17 & 7 & \\
\hline \multicolumn{5}{|l|}{ Tumor stage } \\
\hline I & 1 & 1 & 0 & \multirow{4}{*}{0.690} \\
\hline II & 4 & 3 & 1 & \\
\hline III & 20 & 15 & 5 & \\
\hline IV & 4 & 2 & 2 & \\
\hline \multicolumn{5}{|l|}{ Normal stage (Lymph node) } \\
\hline 0 & 17 & 13 & 4 & \multirow{2}{*}{0.561} \\
\hline I & 12 & 8 & 4 & \\
\hline \multicolumn{5}{|l|}{ Histological } \\
\hline Papillary carcinoma & 10 & 9 & 1 & \multirow{2}{*}{0.124} \\
\hline Tubular adenocarcinoma & 19 & 13 & 6 & \\
\hline
\end{tabular}

\# 1.5-fold used as cut-off value for dichotomizing low and high GCS expression groups. ${ }^{*} p$-value $<0.05$ statistically significant based on chi-square test. 


\subsection{Altered Expression of Ceramide-Metabolizing Enzymes Following Cisplatin Treatment}

In order to address the role of ceramide glycosylation in CCA, we first determined the basal expression of the three ceramide-metabolizing enzymes (GCS, GBA1, and GBA2) in the two CCA cell lines (KKU-100 and KKU-213A), while basal GBA3 expression was excluded because its specific role is still unclear. A high expression level of GCS was found in both CCA cell lines, whereas the respective expression of GBA1 and GBA2 was low (Figure 3A). We then investigated whether alteration of the ceramide-metabolizing enzymes occurs upon cisplatin treatment of the CCA cell lines. The cytotoxicity effect of cisplatin was tested in the CCA cell lines. The cells were treated with various concentrations of cisplatin at $0,10,20,40$, and $60 \mu \mathrm{M}$. After 24 and $48 \mathrm{~h}$ treatment, cell viability was significantly decreased in a dose- and time-dependent manner. The respective half-maximum inhibitory concentration (IC50) value of cisplatin at 24 and $48 \mathrm{~h}$ was 31.17 and $14.72 \mu \mathrm{M}$ for KKU-100 and 20.98 and $18.82 \mu \mathrm{M}$ for KKU-213A (Figure 3B). The expression of the three ceramidemetabolizing enzymes was then investigated following cisplatin treatment for $24 \mathrm{~h}$. The gene expression experiments revealed that inducible expression of GCS and GBA2 was observed at $20 \mu \mathrm{M}$ cisplatin in both KKU-100 and KKU-213A, and the expression of the enzymes declined at $40 \mu \mathrm{M}$ cisplatin (Figure 3C). The significant induction of GCS and GBA2 expression was most clearly evident in KKU-213A. Additionally, the expression ratio of GCS/GBA2 was decreased in KKU-213A in a dose-dependent manner (Figure 3C). According to the gene expression experiment, GBA1 expression was not detectable in all conditions. Taken together, these findings suggest that the altered expression of GCS and GBA2 would be another anticancer effect of cisplatin in CCA.

\subsection{Suppression of GCS Reduces CCA Cell Growth}

In order to evaluate the role of GCS on CCA progression, the effects of GCS knockdown and PPMP (a chemical GCS inhibitor) on CCA cell growth were investigated. Compared to KKU-100, KKU-213A is a highly aggressive CCA cell line with a high growth rate [25]. KKU-213A has the highest basal GCS expression and significant inducible GCS and GBA2 expression following cisplatin treatment. Thus, KKU-213A was selected as the representative CCA cell line for the follow-up experiment. The GCS mRNA and protein levels were significantly decreased in the siGCS-treated KKU-213A compared to the control cells at both $24 \mathrm{~h}$ and $48 \mathrm{~h}$ (Figure $4 \mathrm{~A}$ and Figure S1). The SRB assay showed that the GCS knockdown significantly reduced cell proliferation at 24 and $48 \mathrm{~h}$ (Figure 4B). A similar observation occurred in the PPMP-treated KKU-213A cells (Figure 4C). The anti-proliferative effect was also clearly seen in the PPMP and GCS knockdown co-treatments. (Figure 4D). Moreover, down-regulation of growth-related genes including CCND1, CCNB1, and CDK4 was observed in both siGCS-treated and PPMP-treated KKU-213 cells (Figure 4E,F). These findings suggest that GCS affects CCA cell growth.

\subsection{Suppression of GCS Enhances Cisplatin Sensitivity}

According to Figure 3C, the inducible expression of GCS was seen in the $20 \mu \mathrm{M}$ cisplatin treatment, and the expression declined following $24 \mathrm{~h}$ of $40 \mu \mathrm{M}$ cisplatin treatment, along with the number of viable cells (Figure 3B). We further investigated whether GCS expression influences the response to cisplatin-especially at low doses (viz., 10 and $20 \mu \mathrm{M}$ ). An inducible expression of GCS was indicated at the 10 and $20 \mu \mathrm{M}$ cisplatin treatment (Figure 5A). The siGCS-treated KKU-213A cells and the control cells were exposed to 0, 10 , and $20 \mu \mathrm{M}$ of cisplatin. GCS silencing increased cisplatin-induced CCA cell death by reducing viable cells in a dose-dependent manner compared to the control cells (Figure 5B).

Furthermore, GCS suppression using $10 \mu \mathrm{M}$ PPMP treatment increased the anticancer effect of cisplatin in a dose- and time-dependent manner (Figure 5C). Nevertheless, co-treatment between GCS knockdown, PPMP, and cisplatin showed no further increase in the anticancer effect on CCA cell lines (Figure 5D). This finding suggests that inhibition of GCS using either knockdown or PPMP treatment is sufficient for GCS suppression. Thus, our findings indicate that the inhibition of GCS has a chemosensitizing effect on CCA, 
such that cisplatin and cisplatin-induced CCA cell death may involve an imbalance in the process of ceramide glycosylation through GCS and GBA2 expression.

$\mathbf{A}$

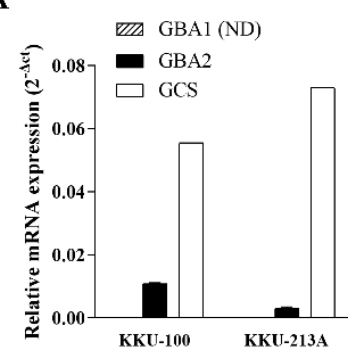

B

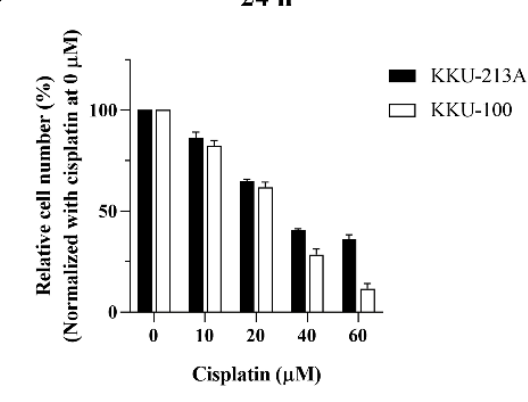

$48 \mathrm{~h}$

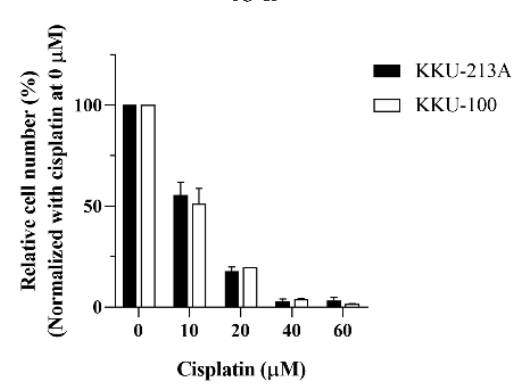

GBA2

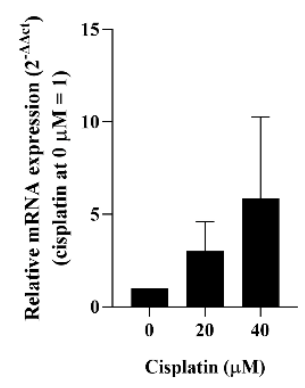

GBA2

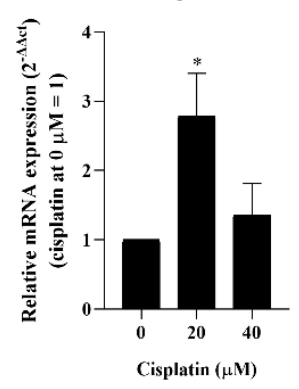

GCS/GBA2 ratio

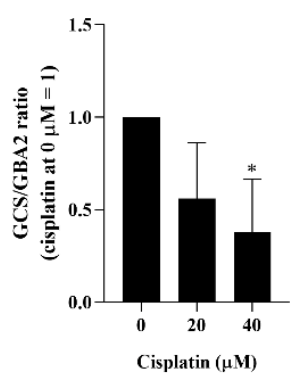

GCS/GBA2 ratio

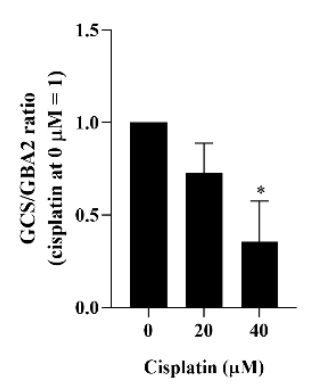

Figure 3. Changes of ceramide-metabolizing enzymes upon cisplatin treatment. (A) Respective basal mRNA expression of GCS, GBA1, and GBA2 were determined in two CCA cell lines (KKU-100 and KKU-213A). (B) KKU-100 and KKU-213A were treated with cisplatin at 0, 10, 20, 40, and $60 \mu \mathrm{M}$ for 24 and $48 \mathrm{~h}$. (C) Respective mRNA expression of GCS, GBA2, and GCS/GBA2 ratio was determined in KKU-100 and KKU-213A after $24 \mathrm{~h}$ of cisplatin treatment. Values are expressed as the mean \pm SEM of three independent experiments. ${ }^{*} p<0.05 ;{ }^{* *} p<0.01$ versus cisplatin at $0 \mu \mathrm{M}$. ND: not detected.

3.5. Suppression of GCS Promotes Cisplatin-Induced CCA Apoptosis through the Inhibition of the ERK Signaling Pathway

In order to elucidate the underlying mechanism of GCS inhibition-increased cisplatininduced CCA cell death (i.e., in KKU-213A cells), GCS was suppressed by $10 \mu \mathrm{M}$ PPMP and co-treated with 10 or $20 \mu \mathrm{M}$ cisplatin. The apoptosis-related markers were then investigated. The immunoblotting assay of KKU-213A confirmed dose-dependent up-regulation of cleaved PARP1 and cleaved caspase- 3 and down-regulation of BCL-2 with co-treatments between PPMP and cisplatin. However, a decreased BCL-2 (pro-apoptotic protein)/BAX (apoptotic protein) ratio was observed in the KKU-213A cell line treated with cisplatin alone at $20 \mu \mathrm{M}$ or co-treated with cisplatin at $20 \mu \mathrm{M}$ and PPMP at $10 \mu \mathrm{M}$. However, none of these apoptotic markers was altered upon PPMP exposure (Figures 6A and S2). Subsequently, the survival pathways (i.e., PI3K/AKT and ERK) were investigated. Interestingly, suppression of GCS significantly reduced the phosphorylation and activation of ERK following cisplatin 
treatment at 10 and $20 \mu \mathrm{M}$, while no activation of AKT was observed after GCS inhibition (Figures 6B and S2). These findings suggest that GCS suppression enhanced cisplatininduced CCA apoptosis through the attenuation of the ERK signaling pathway.

A

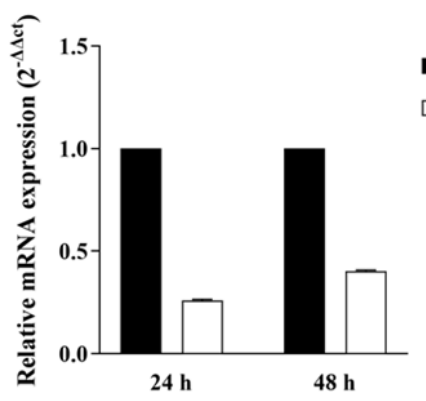

C

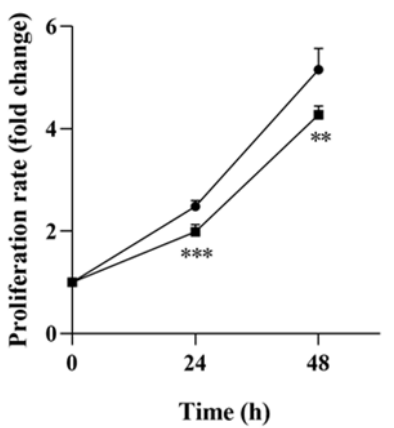

E

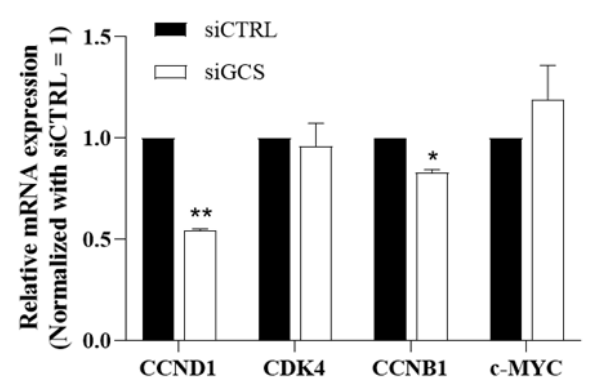

B

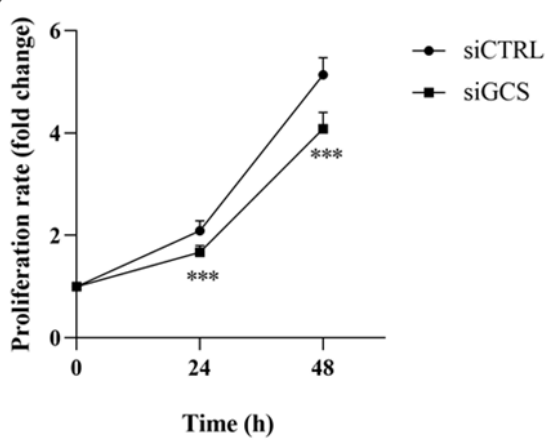

D
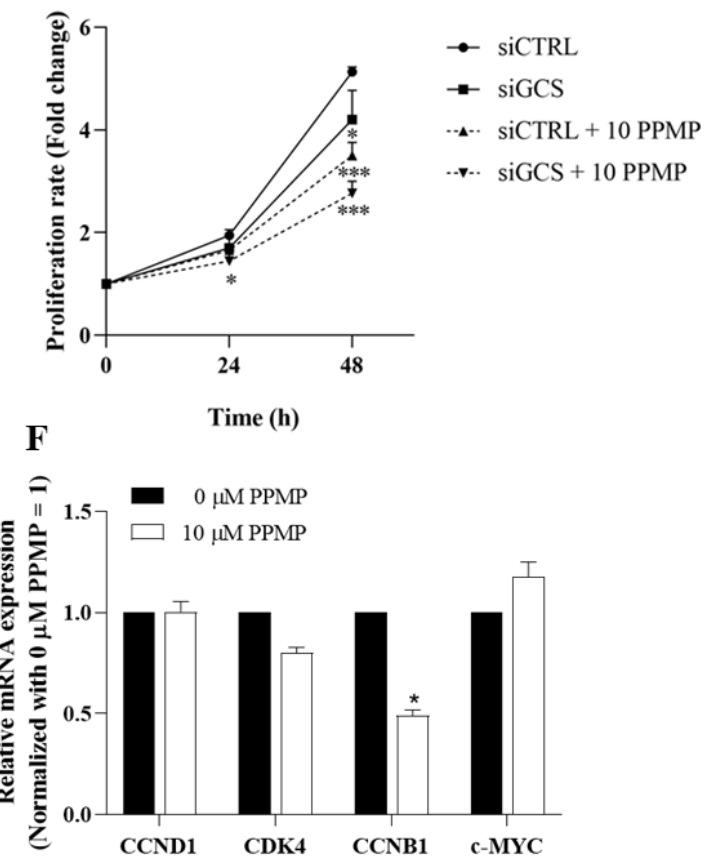

Figure 4. Suppression of GCS reduces CCA cell growth. (A) mRNA and protein levels of GCS after suppression by siRNAs for 24 and $48 \mathrm{~h}$. (B) Cell proliferation after GCS suppression by siRNAs for 0-48 h, (C) PPMP (GCS inhibitor), and (D) co-treatment by siRNAs and PPMP. (E,F) The relative mRNA expression of growth-related genes in siGCS-treated KKU-213A or PPMP-treated KKU213A were determined using qPCR. Values are expressed as the mean $\pm \mathrm{SEM}$ of three independent experiments. ${ }^{*} p<0.05 ;{ }^{* *} p<0.01 ;{ }^{* *} p<0.001$ versus siCTRL. The original unedited blot was presented in Figure S1. 
A

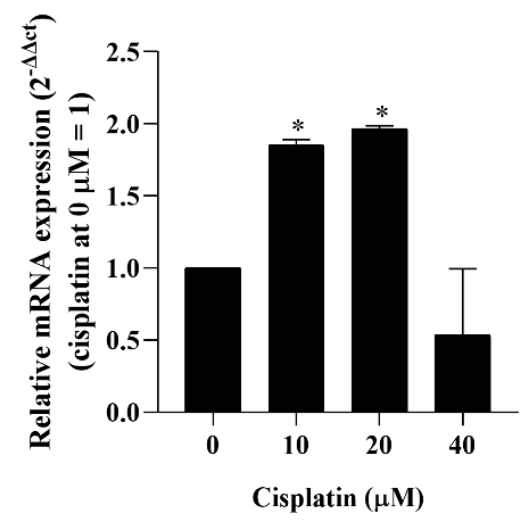

C PPMP and cisplatin co-treatment

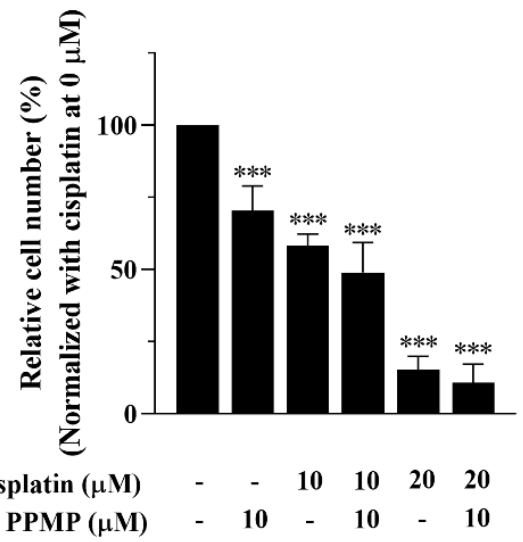

B siRNA and cisplatin co-treatment

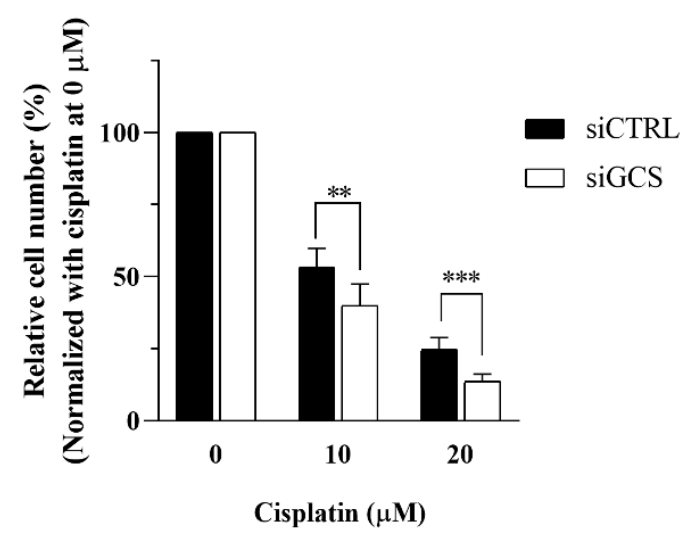

D siRNA, PPMP, and cisplatin co-treatment

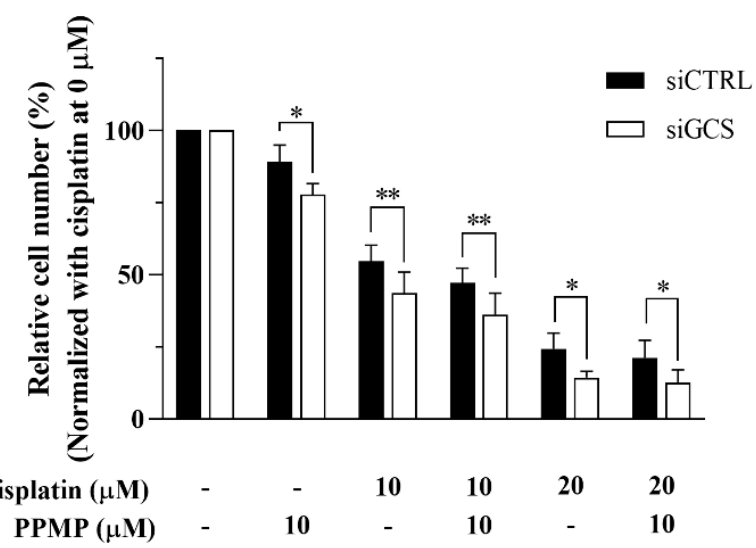

Figure 5. Suppression of GCS enhances cisplatin sensitivity. (A) Inducible mRNA expression of GCS following low-dose cisplatin $(0,10,20$, and $40 \mu \mathrm{M})$. Cell viability of KKU-213A was determined after (B) GCS inhibition by siRNAs for $24 \mathrm{~h}$ and treated with cisplatin for $48 \mathrm{~h}$, (C) GCS inhibition by PPMP for $24 \mathrm{~h}$ and in combination with cisplatin for $48 \mathrm{~h}$, and (D) co-treatment of GCS with siRNAs and PPMP for $24 \mathrm{~h}$ plus cisplatin for $48 \mathrm{~h}$. Values are expressed as the mean \pm SEM of three independent experiments. ${ }^{*} p<0.05$; ${ }^{* *} p<0.01 ;{ }^{* * *} p<0.001$ versus cisplatin at $0 \mu \mathrm{M}$. 
A

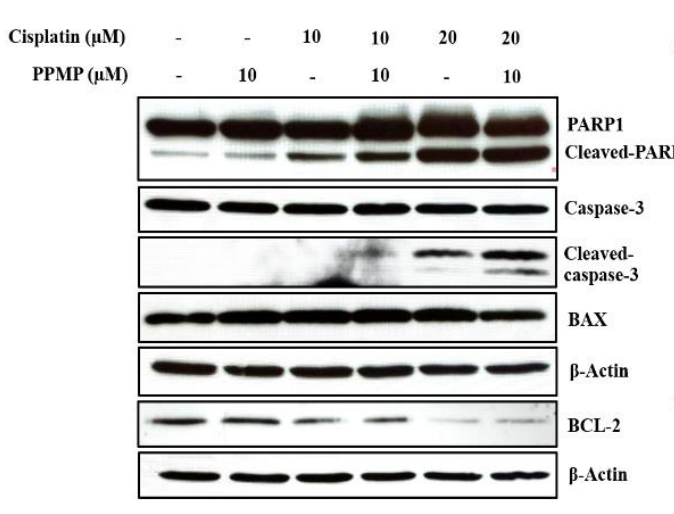

Cisplatin ( $\mu \mathrm{M})$

B

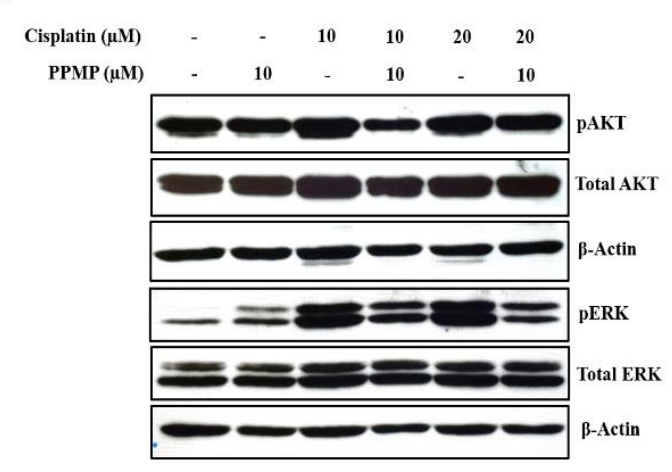

PARP1

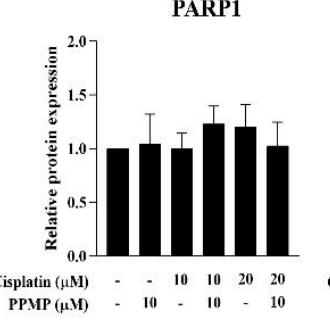

$\operatorname{PPMP}(\mu \mathrm{M})$
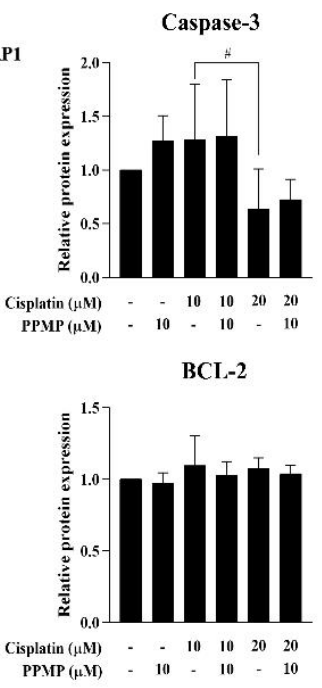

AKT

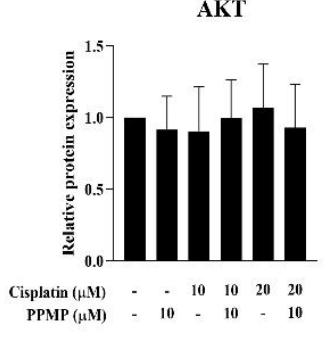

ERK

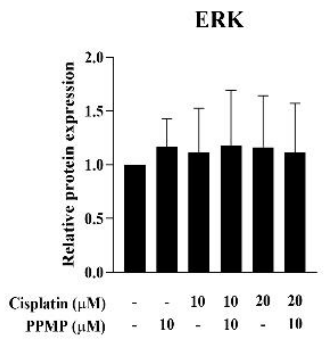

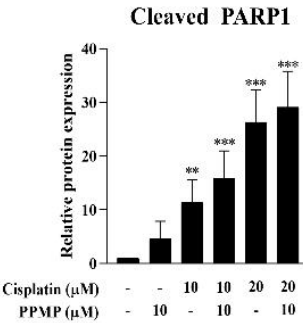

Cleaved caspase-3

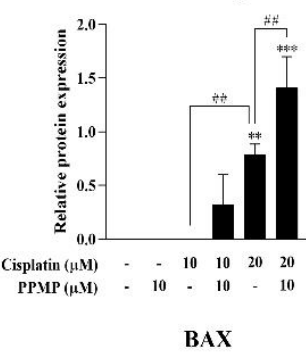

BAX

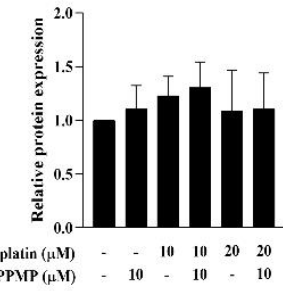

PAKT
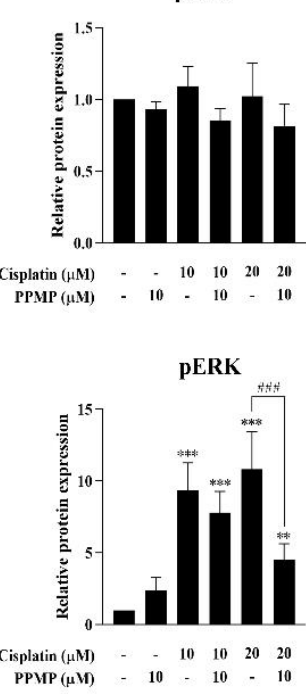
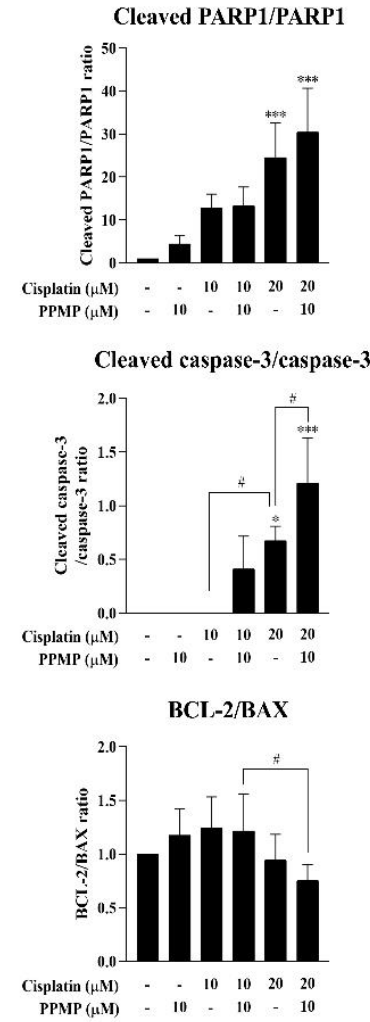

pAKT/AKT

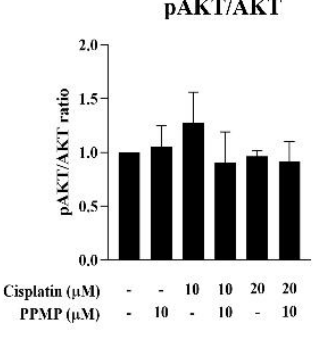

pERK/ERK

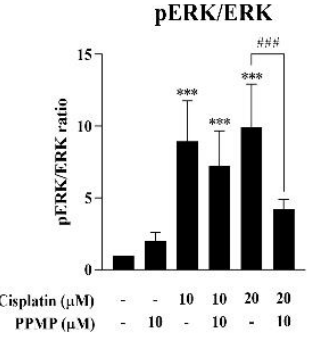

Figure 6. Suppression of GCS induces CCA cell apoptosis via the attenuation of ERK activation. KKU-213A was exposed by PPMP alone $(10 \mu \mathrm{M})$, cisplatin alone $(10$ or $20 \mu \mathrm{M})$, or the combination of both for $24 \mathrm{~h}$. Protein expression potentially involved (A) apoptosis and (B) survival signaling pathway observed by Western blot assay. Relative protein expression was measured by Image J software (version 1.53a). Values are expressed as the mean \pm SEM of three independent experiments. ${ }^{*} p<0.05 ;{ }^{* *} p<0.01 ;{ }^{* * *} p<0.001$ versus cisplatin at $0 \mu \mathrm{M}$. ${ }^{\#} p<0.05$; ${ }^{\# \#} p<0.01$; ${ }^{\# \# \# ~} p<0.001$ versus cisplatin at 10 or $20 \mu \mathrm{M}$. The original unedited blot was presented in Figure S2.

\section{Discussion}

Ceramide glycosylation eliminates the anticancer effect of ceramide, thereby promoting cancer cell growth and survival [27]. Glucosylceramide synthase is a key enzyme that catalyzes the conversion of ceramide to glucosylceramide, a synthesis precursor to 
most complex glycosphingolipids (GSLs) [28-30]. There is growing evidence that GCS is up-regulated in multiple types of cancer, and its expression is associated with the progression of cancer and drug resistance [22,31-33]. According to the GEO database, GCS was overexpressed in CCA tumor tissues and showed higher expression than the two glucosylceramide-degrading enzymes, GBA1 and GBA2. However, verification of GCS mRNA expression in 29 pairs of matched tumor and adjacent normal samples showed only $27.6 \%$ (8/29 cases) of tumor tissues having high GCS mRNA expression relative to the adjacent tissue. We demonstrated no significant correlation between GCS mRNA expression, survival, and clinicopathological variables in CCA, possibly because of the small sample used and the low prognostic value of GCS expression in cancer patients. Therefore, the verification of the increased GCS expression at protein levels in large sample size and clinical correlations are required in further investigations. High expression of GCS was, however, confirmed in two CCA cell lines where no GBA1 expression and low GBA2 expression were detected. The results suggest that aberrant expression of ceramide-metabolizing enzymes occurs in CCA. Additionally, high GCS expression in CCA is consistent with the studies on lipidomic measurements in CCA tissues, in which high levels of hexosylceramides and lactosylceramides are observed in CCA tissues, and these levels were associated with short survival of the CCA patients $[34,35]$. Up-regulation of GCS is implicated in cancer progression and multi-drug resistance, but the role of glucosylceramide breakdown (including GBA1 and GBA2) in cancer is unclear. Expression of GBA1 and GBA2 varies among cancer cell types. For example, down-regulation of GBA1 and GBA2 was found in colon cancer, whereas overexpression of GBA1 was observed in breast cancer [36]. Furthermore, suppression of GBA1 using siRNA induced paclitaxel resistance and the activation of the AKT pathway in three different cancer cell lines, including colon carcinoma, breast adenocarcinoma, and non-small-cell lung carcinoma [37].

GCS is involved in various malignant phenotypes, including cell growth, metastasis, and drug resistance $[19,38]$. The molecular mechanism of GCS on tumor progression and multi-drug resistance through the PI3K/AKT, MAPK/ERK, and c-Src/ $\beta$-catenin signaling pathways is well-defined [39]. Additionally, GCS expression can be induced by anticancer drugs (viz., doxorubicin and cisplatin), leading to drug resistance in several types of cancer cells $[40,41]$. Therefore, cisplatin has been used in advanced CCA treatment alone or with other agents [9,42]. In the present study, cisplatin exhibited an anticancer effect in both the CCA cell lines in a dose- and time-dependent manner.

Interestingly, GCS and GBA2 expression were both significantly induced in the KKU-213A cell line at a lower dose of cisplatin $(10$ and $20 \mu \mathrm{M})$. The low GCS/GBA2 expression ratio highlighted the likelihood that aberrant ceramide glycosylation may be involved in the anticancer activity of cisplatin in CCA. However, the expression of GCS and GBA2 in KKU-100 were slightly changed following the cisplatin treatment. These results indicate that alteration of ceramide glycosylation upon cisplatin treatment may depend on each CCA cell line's genetic background and malignant characteristics including anatomical location and malignant phenotypes. KKU-100 is a slow growing cell line that was established from a perihilar-CCA-containing wild type TP53 and mutant Kras, whereas KKU-213 is a highly aggressive CCA cell line which was established from intrahepatic CCA containing both TP53 and Kras mutations [24,25]. These findings agree with other studies on gemcitabine treatment and other anticancer agents, in which intracellular metabolic alterations and/or different mechanisms of drug resistance determine the differential response of each CCA cell line to particular chemotherapeutic agents [26,43-45].

Overexpression of GCS is mainly found in multi-drug-resistant cells in several types of cancer and contributes to a poor response to chemotherapy [31]. Inhibition of GCS shows increased chemosensitivity of cancer cells to various anticancer drugs (i.e., sorafenib, cisplatin, and doxorubicin) [42,46,47]. We further investigated whether GCS is implicated in CCA progression and drug resistance. Suppression of GCS using the chemical inhibitor (PPMP) or specific siRNA to GCS significantly reduced CCA cell growth and decreased the transcription levels of growth-related genes. Moreover, an anti-proliferative effect was seen 
in PPMP and GCS knockdown co-treatments. These results are consistent with previous studies in hepatocellular carcinoma and colon cancer, in which the disruption of ceramide homeostasis by GCS inhibition using RNA interference contributed to a reduction of tumor growth $[22,48,49]$. Moreover, GCS suppression using a chemical GCS inhibitor induced an increased ceramide level, leading to an inhibition of cell growth in melanoma cancer and head and neck cancer [22,40,50]. However, the effect of GCS on CCA cell growth is preliminary, and further study is needed on the association between GCS inhibition-induced ceramide production and CCA cell growth to confirm our findings.

Inhibition of GCS increased the chemosensitivity of CCA cell lines to low-dose cisplatin $(10$ and $20 \mu \mathrm{M})$, where GCS expression was induced. However, the decrease in the transcriptional levels of $A B C$ transporter superfamily including $A B C B 1$ (MDR1), ABCC1, $A B C C 3$, and ABCG2 was not observed after GCS suppression (data not shown). This result indicates that induction of GCS expression by low-dose cisplatin may serve as a survival mechanism to protect ceramide levels from increased GBA2 activity and attenuate cisplatin-induced CCA cell death. Subsequently, inhibition of GCS (using PPMP) enhanced cisplatin-induced CCA apoptosis via up-regulation of cleaved caspase-3 and cleaved PARP1 and down-regulation of BCL-2. These findings are consistent with studies of head and neck cancer and colon cancer, in which GCS inhibition down-regulates MDR1 expression and induces ceramide-mediated apoptosis in cisplatin-resistant cells [41,48]. As such, GCS is a promising target to enhance the chemosensitivity of CCA to cisplatin. However, further study with other GCS inhibitors such as eliglustat, which is used for Gaucher's disease in a clinical setting, and in vivo experiments are needed to clarify the significant role of GCS for chemoresistance in CCA. The accumulation of glycosphingolipids (GSLs), especially glucosylceramide, promotes cancer and drug resistance progression through various signal transduction mechanisms, including the c-Src/ $\beta$-catenin, PI3K/AKT, and ERK pathways. The activation of both the AKT and ERK pathways plays a major role in the carcinogenesis of CCA and cisplatin resistance [51,52]. The present study demonstrates that phosphorylation and activation of ERK were increased following low-dose cisplatin treatment where inducible GCS expression was observed. Suppression of GCS by PPMP greatly reduced the phosphorylation and activation of ERK following cisplatin treatment, while no activation of AKT was observed after GCS inhibition. These findings suggest that GCS suppression enhanced cisplatin-induced CCA apoptosis through the attenuation of the ERK signaling pathway. These findings are consistent with published reports that GCS knockdown down-regulates anti-apoptotic protein BCL-2 by limiting the activation of the ERK signaling pathway [53].

In summary, our results demonstrate that GCS was up-regulated in CCA. The induction of GCS expression was detected in CCA cell lines following low-dose cisplatin treatment. Blocking ceramide glycosylation by inhibiting GCS attenuated the progression of CCA by reducing CCA cell growth and sensitizing CCA cells to low-dose cisplatin. Knockdown of GCS enhanced cisplatin-induced CCA apoptosis by diminishing the activation of the ERK-signaling pathway. As a result, targeting GCS may be a potential strategy for improving CCA treatment.

Supplementary Materials: The following supporting information can be downloaded at: https: / www. mdpi.com/article/10.3390/life12030351/s1, Figure S1: Original unedited blot of GCS and $\beta$-actin for representative Western blots used in Figure 4A of the manuscript; Figure S2: Original unedited blot of PARP, cleaved-PARP, caspase-3, cleavage-caspase-3, BCL-2, BAX, AKT, pAKT, ERK, pERK and $\beta$-actin for representative Western blots used in Figure $6 \mathrm{~A}, \mathrm{~B}$ of the manuscript.

Author Contributions: C.T. conceived and designed the study. P.C. and C.T. performed the experiments. P.C. drafted the manuscript. C.T., K.T., P.J. and J.R.K.C. guided the experimental designs and data analyses. C.T. and J.R.K.C. revised the manuscript. All authors have read and agreed to the published version of the manuscript. 
Funding: This work was supported by the Thailand Research Fund under Grant no. RSA6180017 to Krajang Talabnin, SUT Research Unit grants to Chutima Talabnin, and the Development and Promotion of Science and Technology Talents Project (DPST) for funding and scholarship to Piyasiri Chueakwon.

Institutional Review Board Statement: The study was conducted in accordance with the Declaration of Helsinki and approved by the Ethics Committee for Human Research from Khon Kaen University and Suranaree University of Technology (protocol code HE521209 and EC-57-25) for studies involving humans.

Informed Consent Statement: Informed consent was obtained from all subjects involved in the study.

Data Availability Statement: The data presented in this study are included in this published article.

Acknowledgments: We thank Bryan Roderick Hamman for assistance with the English-language presentation of the manuscript.

Conflicts of Interest: The authors declare that they have no conflict of interest.

\section{References}

1. Banales, J.M.; Cardinale, V.; Carpino, G.; Marzioni, M.; Andersen, J.B.; Invernizzi, P.; Lind, G.E.; Folseraas, T.; Forbes, S.J.; Fouassier, L.; et al. Cholangiocarcinoma: Current knowledge and future perspectives consensus statement from the European Network for the Study of Cholangiocarcinoma (ENS-CCA). Nat. Rev. Gastroenterol. Hepatol. 2016, 13, 261-280. [CrossRef]

2. Anderson, C.D.; Pinson, C.W.; Berlin, J.; Chari, R.S. Diagnosis and Treatment of Cholangiocarcinoma. Oncologist 2004, 9, 43-57. [CrossRef]

3. Banales, J.M.; Marin, J.J.G.; Lamarca, A.; Rodrigues, P.M.; Khan, S.A.; Roberts, L.R.; Cardinale, V.; Carpino, G.; Andersen, J.B.; Braconi, C.; et al. Cholangiocarcinoma 2020: The next horizon in mechanisms and management. Nat. Rev. Gastroenterol. Hepatol. 2020, 17, 557-588. [CrossRef]

4. Markussen, A.; Jensen, L.H.; Diness, L.V.; Larsen, F.O. Treatment of Patients with Advanced Biliary Tract Cancer with Either Oxaliplatin, Gemcitabine, and Capecitabine or Cisplatin and Gemcitabine-A Randomized Phase II Trial. Cancers 2020, $12,1975$. [CrossRef]

5. Lee, M.A.; Woo, I.S.; Kang, J.-H.; Hong, Y.S.; Lee, K.S. Gemcitabine and cisplatin combination chemotherapy in intrahepatic cholan-giocarcinoma as second-line treatment: Report of Four Cases. Jpn. J. Clin. Oncol. 2004, 34, 547-550. [CrossRef]

6. Adeva, J.; Sangro, B.; Salati, M.; Edeline, J.; La Casta, A.; Bittoni, A.; Berardi, R.; Bruix, J.; Valle, J.W. Medical treatment for cholangiocarcinoma. Liver Int. 2019, 39, 123-142. [CrossRef]

7. Alqahtani, S.A.; Colombo, M. Systemic therapy for advanced cholangiocarcinoma: New options on the horizon. Hepatoma Res. 2020, 6, 70. [CrossRef]

8. Li, Q.; Xia, X.; Ji, J.; Ma, J.; Tao, L.; Mo, L.; Chen, W. MiR-199a-3p enhances cisplatin sensitivity of cholangiocarcinoma cells by inhibiting mTOR signaling pathway and expression of MDR1. Oncotarget 2017, 8, 33621-33630. [CrossRef]

9. Asgar, M.A.; Senawong, G.; Sripa, B.; Senawong, T. Scopoletin potentiates the anti-cancer effects of cisplatin against cholangiocarcinoma cell lines. Bangladesh J. Pharmacol. 2015, 10, 69-77. [CrossRef]

10. Wang, H.; Guo, S.; Kim, S.-J.; Shao, F.; Ho, J.W.K.; Wong, K.U.; Miao, Z.; Hao, D.; Zhao, M.; Xu, J.; et al. Cisplatin prevents breast cancer metastasis through blocking early EMT and retards cancer growth together with paclitaxel. Theranostics 2021, 11, 2442-2459. [CrossRef] [PubMed]

11. Sheridan, M.; Ogretmen, B. The Role of Ceramide Metabolism and Signaling in the Regulation of Mitophagy and Cancer Therapy. Cancers 2021, 13, 2475. [CrossRef]

12. Liu, Y.-Y.; Gupta, V.; A Patwardhan, G.; Bhinge, K.; Zhao, Y.; Bao, J.; Mehendale, H.; Cabot, M.C.; Li, Y.-T.; Jazwinski, S.M. Glucosylceramide synthase upregulates MDR1 expression in the regulation of cancer drug resistance through cSrc and $\beta$-catenin signaling. Mol. Cancer 2010, 9, 145. [CrossRef] [PubMed]

13. Dupre, T.; Doll, M.A.; Shah, P.P.; Sharp, C.N.; Siow, D.; Megyesi, J.; Shayman, J.; Bielawska, A.; Bielawski, J.; Beverly, L.J.; et al. Inhibiting glucosylceramide synthase exacerbates cisplatin-induced acute kidney injury. J. Lipid Res. 2017, 58, 1439-1452. [CrossRef] [PubMed]

14. Ghosh, S.; Jawed, J.J.; Halder, K.; Banerjee, S.; Chowdhury, B.P.; Saha, A.; Juin, S.K.; Majumdar, S.B.; Bose, A.; Baral, R.; et al. $\mathrm{TNF} \alpha$ mediated ceramide generation triggers cisplatin induced apoptosis in B16F10 melanoma in a PKC $\delta$ independent manner. Oncotarget 2018, 9, 37627-37646. [CrossRef]

15. Li, Y.-L.; Lin, M.-L.; He, S.-Q.; Jin, J.-F. Sphingolipid metabolism affects the anticancer effect of cisplatin. World J. Transl. Med. 2016, 5, 37-45. [CrossRef]

16. Xie, P.; Shen, Y.-F.; Shi, Y.-P.; Ge, S.-M.; Gu, Z.-H.; Wang, J.; Mu, H.-J.; Zhang, B.; Qiao, W.-Z.; Xie, K.-M. Overexpression of glucosylceramide synthase in associated with multidrug resistance of leukemia cells. Leuk. Res. 2008, 32, 475-480. [CrossRef]

17. Quinville, B.M.; Deschenes, N.M.; Ryckman, A.E.; Walia, J.S. A Comprehensive Review: Sphingolipid Metabolism and Implications of Disruption in Sphingolipid Homeostasis. Int. J. Mol. Sci. 2021, 22, 5793. [CrossRef] [PubMed] 
18. Jatooratthawichot, P.; Talabnin, C.; Ngiwsara, L.; Rustam, Y.H.; Svasti, J.; Reid, G.E.; Ketudat Cairns, J.R. Effect of expression of human gluco-sylceramidase 2 isoforms on lipid profiles in COS-7 cells. Metabolites 2020, 10, 488. [CrossRef]

19. Liu, Y.-Y.; Patwardhan, G.A.; Xie, P.; Gu, X.; Giuliano, A.E.; Cabot, M.C. Glucosylceramide synthase, a factor in modulating drug resistance, is overexpressed in metastatic breast carcinoma. Int. J. Oncol. 2011, 39, 425-431. [CrossRef]

20. Chiu, W.-H.; Su, W.-C.; Li, C.-L.; Chen, C.-L.; Lin, C.-F. An increase in glucosylceramide synthase induces Bcl-xL-mediated cell survival in vinorelbine-resistant lung adenocarcinoma cells. Oncotarget 2015, 6, 20513-20524. [CrossRef]

21. Wang, C.; Liu, J.N.; Xu, L.; Mu, Y.L.; Sun, P. Expression and significance of glucosylceramide synthase in colorectal carcinoma tissues. Eur. Rev. Med Pharmacol. Sci. 2014, 18, 3632-3637.

22. Jennemann, R.; Federico, G.; Mathow, D.; Rabionet, M.; Rampoldi, F.; Popovic, Z.V.; Volz, M.; Hielscher, T.; Sandhoff, R.; Gröne, H.-J. Inhibition of hepatocellular carcinoma growth by blockade of glycosphingolipid synthesis. Oncotarget 2017, 8, 109201-109216. [CrossRef]

23. Chaisaingmongkol, J.; Budhu, A.; Dang, H.; Rabibhadana, S.; Pupacdi, B.; Kwon, S.M.; Forgues, M.; Pomyen, Y.; Bhudhisawasdi, V.; Lertprasertsuke, N.; et al. Common Molecular Subtypes Among Asian Hepatocellular Carcinoma and Cholangiocarcinoma. Cancer Cell 2017, 32, 57-70.e3. [CrossRef]

24. Sripa, B.; Leungwattanawanit, S.; Nitta, T.; Wongkham, C.; Bhudhisawasdi, V.; Puapairoj, A.; Sripa, C.; Miwa, M. Establishment and characterization of an opisthorchiasis-associated cholangiocarcinoma cell line (KKU-100). World J. Gastroenterol. WJG 2005, 11, 3392-3397. [CrossRef] [PubMed]

25. Sripa, B.; Seubwai, W.; Vaeteewoottacharn, K.; Sawanyawisuth, K.; Silsirivanit, A.; Kaewkong, W.; Muisuk, K.; Dana, P.; Phoomak, C.; Lert-Itthiporn, W.; et al. Functional and genetic characterization of three cell lines derived from a single tumor of an Opisthorchis viverrini-associated cholangiocarcinoma patient. Hum. Cell 2020, 33, 695-708. [CrossRef]

26. Livak, K.J.; Schmittgen, T.D. Analysis of relative gene expression data using real-time quantitative PCR and the $2^{-\Delta \Delta C T}$ method. Methods 2001, 25, 402-408. [CrossRef]

27. Li, Z.; Zhang, L.; Liu, D.; Wang, C. Ceramide glycosylation and related enzymes in cancer signaling and therapy. Biomed. Pharmacother. 2021, 139, 111565. [CrossRef]

28. Liu, Y.-Y.; Hill, R.A.; Li, Y.-T. Ceramide glycosylation catalyzed by glucosylceramide synthase and cancer drug resistance. Adv. Cancer Res. 2013, 117, 59-89.

29. Kreitzburg, K.M.; van Waardenburg, R.C.; Yoon, K.J. Sphingolipid metabolism and drug resistance in ovarian cancer. Cancer Drug Resist. 2018, 1, 181-197. [CrossRef] [PubMed]

30. Wegner, M.-S.; Gruber, L.; Mattjus, P.; Geisslinger, G.; Grösch, S. The UDP-glucose ceramide glycosyltransferase (UGCG) and the link to multidrug resistance protein 1 (MDR1). BMC Cancer 2018, 18, 153. [CrossRef]

31. Gupta, V.; Liu, Y.-Y. New Insights on Glucosylceramide Synthase in Cancer drug resistance and myelosuppression. Biochem. Pharmacol. 2013, 2, 19840.

32. Liu, Y.-Y.; Han, T.Y.; Yu, J.Y.; Bitterman, A.; Le, A.; Giuliano, A.E.; Cabot, M.C. Oligonucleotides blocking glucosylceramide synthase expression selectively reverse drug resistance in cancer cells. J. Lipid Res. 2004, 45, 933-940. [CrossRef] [PubMed]

33. Liu, Y.-Y.; Patwardhan, G.A.; Bhinge, K.; Gupta, V.; Gu, X.; Jazwinski, S.M. Suppression of glucosylceramide synthase restores p53-dependent apoptosis in mutant p53 cancer cells. Cancer Res. 2011, 71, 2276-2285. [CrossRef]

34. Silsirivanit, A.; Phoomak, C.; Teeravirote, K.; Wattanavises, S.; Seubwai, W.; Saengboonmee, C.; Zhan, Z.; Inokuchi, J.I.; Suzuki, A.; Wongkham, S. Overexpression of HexCer and LacCer containing 2-hydroxylated fatty acids in cholangiocarcinoma and the association of the increase of LacCer (d18:1-h23:0) with shorter survival of the patients. Glycoconj. J. 2019, 36, 103-111. [CrossRef]

35. Talabnin, K.; Talabnin, C.; Kumagai, T.; Sutatum, N.; Khiaowichit, J.; Dechsukhum, C.; Ishihara, M.; Azadi, P.; Sripa, B. Ganglioside GM2: A potential biomarker for cholangiocarcinoma. J. Int. Med. Res. 2020, 48. [CrossRef]

36. Astudillo, L.; Therville, N.; Colacios, C.; Ségui, B.; Andrieu-Abadie, N.; Levade, T. Glucosylceramidases and malignancies in mammals. Biochimie 2016, 125, 267-280. [CrossRef] [PubMed]

37. Swanton, C.; Marani, M.; Pardo, O.; Warne, P.H.; Kelly, G.; Sahai, E.; Elustondo, F.; Chang, J.; Temple, J.; Ahmed, A.A.; et al. Regulators of mitotic arrest and ceramide metabolism are determinants of sensitivity to paclitaxel and other chemotherapeutic drugs. Cancer Cell 2007, 11, 498-512. [CrossRef]

38. Bleicher, R.J.; Cabot, M.C. Glucosylceramide synthase and apoptosis. Biochim. Biophys. Acta (BBA)-Mol. Cell Biol. Lipids 2002, 1585, 172-178. [CrossRef]

39. Gupta, V.; Bhinge, K.N.; Hosain, S.B.; Xiong, K.; Gu, X.; Shi, R.; Ho, M.Y.; Khoo, K.H.; Li, S.C.; Li, Y.T.; et al. Ceramide glycosylation by glucosylceramide synthase selectively maintains the properties of breast cancer stem cells. J. Biol. Chem. 2012, 287, 37195-37205. [CrossRef] [PubMed]

40. Roy, K.R.; Uddin, M.B.; Roy, S.C.; Hill, R.A.; Marshall, J.; Li, Y.T.; Chamcheu, J.C.; Lu, H.; Liu, Y.Y. Gb3-cSrc complex in glycosphingolipid-enriched microdomains contributes to the expression of p53 mutant protein and cancer drug resistance via $\beta$-catenin-activated RNA methylation. FASEB BioAdv. 2020, 2, 653-667. [CrossRef]

41. Zhang, X.; Wu, X.; Su, P.; Gao, Y.; Meng, B.; Sun, Y.; Li, L.; Zhou, Z.; Zhou, G. Doxorubicin influences the expression of glucosylceramide synthase in invasive ductal breast cancer. PLOS ONE 2012, 7, e48492. [CrossRef]

42. Roh, J.-L.; Kim, E.H.; Park, J.Y.; Kim, J.W. Inhibition of glucosylceramide synthase sensitizes head and neck cancer to cisplatin. Mol. Cancer Ther. 2015, 14, 1907-1915. [CrossRef] 
43. Talabnin, C.; Talabnin, K.; Wongkham, S. Enhancement of piperlongumine chemosensitivity by silencing heme oxygenase-1 expression in cholangiocarcinoma cell lines. Oncol. Lett. 2020, 20, 2483-2492. [CrossRef]

44. Promraksa, B.; Katrun, P.; Phetcharaburanin, J.; Kittirat, Y.; Namwat, N.; Techasen, A.; Li, J.V.; Loilome, W. Metabolic changes of cholangiocarcinoma cells in response to coniferyl alcohol treatment. Biomolecules 2021, 11, 476. [CrossRef]

45. Seaban, T.; Loilome, W.; Namwat, N.; Phetcharaburanin, J.; Klanrit, P. Extracellular Metabolic profiling of gemcitabine-responsive cholangiocarcinoma cell line. In Proceedings of the 22nd National Graduate Research Conference, Khon Kaen, Thailand, 25 March 2021.

46. Stefanovic, M.; Tutusaus, A.; Martinez-Nieto, G.A.; Bárcena, C.; de Gregorio, E.; Moutinho, C.; Barbero-Camps, E.; Villanueva, A.; Colell, A.; Marí, M.; et al. Targeting glucosylceramide synthase upregulation reverts sorafenib resistance in experimental hepatocellular carcinoma. Oncotarget 2016, 7, 8253-8267. [CrossRef]

47. Hosain, S.B.; Khiste, S.K.; Uddin, M.B.; Vorubindi, V.; Ingram, C.; Zhang, S.; Hill, R.A.; Gu, X.; Liu, Y.Y. Inhibition of glucosylceramide synthase eliminates the oncogenic function of p53 $\mathrm{R} 273 \mathrm{H}$ mutant in the epithelial-mesenchymal transition and induced pluripotency of colon cancer cells. Oncotarget 2016, 7, 60575-60592. [CrossRef]

48. Li, J.F.; Zheng, S.J.; Wang, L.L.; Liu, S.; Ren, F.; Chen, Y.; Bai, L.; Liu, M.; Duan, Z.P. Glucosylceramide synthase regulates the proliferation and apoptosis of liver cells in vitro by Bcl-2/Bax pathway. Mol. Med. Rep. 2017, 16, 7355-7360. [CrossRef] [PubMed]

49. Song, M.; Zang, W.; Zhang, B.; Cao, J.; Yang, G. GCS overexpression is associated with multidrug resistance of human HCT-8 colon cancer cells. J. Exp. Clin. Cancer Res. 2012, 31, 23. [CrossRef]

50. Weiss, M.; Hettmer, S.; Smith, P.; Ladisch, S. Inhibition of melanoma tumor growth by a novel inhibitor of glucosylceramide synthase. Cancer Res. 2003, 63, 3654-3658.

51. Schmitz, K.J.; Lang, H.; Wohlschlaeger, J.; Sotiropoulos, G.C.; Reis, H.; Schmid, K.W.; Baba, H.A. AKT and ERK1/2 signaling in intrahepatic cholangiocarcinoma. World J. Gastroenterol. WJG 2007, 13, 6470. [CrossRef]

52. Siddik, Z.H. Cisplatin: Mode of cytotoxic action and molecular basis of resistance. Oncogene 2003, 22, 7265-7279. [CrossRef] [PubMed]

53. Wang, Q.; Zou, J.; Zhang, X.; Mu, H.; Yin, Y.; Xie, P. Glucosylceramide synthase promotes Bcl-2 expression via the ERK signaling pathway in the K562/ A02 leukemia drug-resistant cell line. Int. J. Hematol. 2014, 100, 559-566. [CrossRef] [PubMed] 